\author{
PAWEŁ CZAPLIŃSKI \\ Uniwersytet Szczeciński, Polska \\ University of Szczecin, Poland
}

\title{
Przemiany w polskim przemyśle przetwórstwa rybnego
}

\section{Changes in Polish Fish Processing Industry}

Streszczenie: Przemysł przetwórstwa rybnego od kilku lat jest uważany za jeden z najszybciej rozwijających się działów przemysłu spożywczego w Polsce. Odgrywa on również znaczącą rolę w zaopatrywaniu rynku Unii Europejskiej w przetwory rybne. Istnieje jednak szereg zagrożeń dla jego dalszego funkcjonowania, tkwiących zarówno w otoczeniu zewnętrznym (bliższym i dalszym), jak i w otoczeniu wewnętrznym. Aktualne problemy krajowego przetwórstwa rybnego mają bardzo zróżnicowaną genezę. Istnieją takie, jak np. problem zaopatrzenia w surowiec, które były sygnalizowane już przed akcesją do struktur UE, ale są również nowe problemy, związane np. z niedoborem zasobów pracy czy brakiem nowoczesnego wsparcia instytucjonalnego. Rozpoznane trudności należy postrzegać nie tylko w perspektywie krótko- czy długookresowej. Warto także dostrzegać ich wagę i wzajemne relacje, które mogą wzmacniać lub osłabiać wyniki działalności gospodarczej pojedynczych podmiotów lub całego sektora. Nie bez znaczenia jest również oddzielenie zjawisk epizodycznych i cyklicznych, które mogą zakłócać poprawną interpretację trendów, zwłaszcza długookresowych. Celem pracy jest identyfikacja podstawowych problemów związanych z działalnością krajowych przedsiębiorstw przetwórstwa rybnego oraz próba określenia ich wpływu na podstawowe struktury przemysłu, w tym na strukturę produkcji, zatrudnienia, zbytu, a ostatecznie także na strukturę przestrzenną.

\begin{abstract}
Fish processing industry for several years now is considered as one of the fastest developing sectors of food industry in Poland. It also plays an important role in supplying the EU market in processed fish products. However, there is an array of threats for its further functioning that have roots both in external environment (closer and further) and in internal environment. The present problems of national fish processing industry have a very diverse genesis. Among them there is e.g. the problem of supplying in raw materials, which was indicated already before the accession to the EU structures, but there are also new problems connected with e.g. the shortage of labour force or the lack of modern institutional support. The identification of difficulties should be seen not only in short- or long term perspective. It is also worth to see their importance and mutual relations that can either strengthen or weaken the results of economic activity of single entities or the entire sector. Another important thing is also the separation of episodic and cyclical phenomena, which may disturb correct interpretation of long-term trends in particular. The aim of the paper is the identification of basic problems connected with the functioning of national fish processing companies and an attempt to specify their influence on basic structures of the industry, including the structure of production, employment, market and ultimately the spatial structure.
\end{abstract}

Słowa kluczowe: przemysł przetwórstwa rybnego; przemysł spożywczy; przetwory rybne; struktury przemysłu

Keywords: fish processing industry; food industry; processed fish products; the structures of industry 
Otrzymano: 26 stycznia 2018

Received: 26 January 2018

Zaakceptowano: 21 maja 2018

Accepted: 21 May 2018

Sugerowana cytacja / Suggested citation:

Czapliński, P. (2018). Przemiany w polskim przemyśle przetwórstwa rybnego. Prace Komisji Geografii Przemysłu Polskiego Towarzystwa Geograficznego, 32(2), 60-72. https://doi.org/10.24917/20801653.322.4

\section{WSTĘP}

Współczesne studia dotyczące przemian strukturalnych przemysłu przetwórstwa rybnego w Polsce obejmują najczęściej aspekty makroekonomiczne w ujęciu aprzestrzennym (m.in. Kapusta, 2014). Za nieliczne należy również uznać prace, w których prezentowane są wybrane elementy struktury przestrzennej omawianej działalności gospodarczej, jednak bez pełnego wykorzystania modelu nomologiczno-dedukcyjnego (Hryszko, Kuzebski, Lirski, 2014; Kieliszewska, 2016). Wychodząc więc naprzeciw potrzebom środowiska przetwórców ryb, a jednocześnie wypełniając jeden ze współczesnych postulatów badań geograficznych, który dotyczy wykorzystania i pokazywania użyteczności geografii dla opisu i wyjaśniania współczesnych procesów gospodarczych (Kostrzewski, Roo-Zielińska, 2011; Śleszyński, 2016), podjęto kolejną próbę badań nad funkcjonowaniem przedsiębiorstw przemysłu przetwórstwa rybnego, ze szczególnym uwzględnieniem konsekwencji przestrzennych (Czapliński, 2011 i inni).

Podstawą niniejszych rozważań jest model wpływu reguł rozwoju na przemiany przemysłu Z. Zioły (2006) (ryc. 1). W ramach tego modelu przyjęto, że „efekty zmian w przemyśle wiążą się z przyjmowaniem określonych zasad, wynikających z prawidłowości kształtowania się procesów w skali makro-, mezo- oraz mikroekonomicznej, które mają charakter aprzestrzenny i niekiedy w różnym stopniu oddziałują na kierunki rozwoju przestrzeni społeczno-gospodarczej, przestrzeni przemysłowej oraz poszczególnych przedsiębiorstw, zróżnicowanych pod względem potencjału, reprezentowanej branży, powiązań kapitałowo-produkcyjnych i rynkowych" (Zioło, 2006: 14). Według cytowanego autora dla pełniejszej analizy wpływu reguł na przemiany przemysłu należy badać zachodzące między nimi relacje. Ponadto według Zioły (2006: 14): „znaczną rolę (...) odgrywają także zmiany uwarunkowań przestrzennych, które wynikają z określonego poziomu rozwoju i zaznaczających się kierunków przemian społeczno-gospodarczych i kulturowych". Nakładające się procesy ekonomiczne na zróżnicowane uwarunkowania przestrzenne dają często odmienne efekty, zaznaczające się zarówno w układzie europejskim, jak i w uwarunkowaniach krajowych, regionalnych i lokalnych.

Należy również poczynić uwagę, że przemysł przetwórstwa rybnego to całokształt zagadnień składających się na działalność gospodarczą związaną z przetwarzaniem i konserwowaniem ryb, skorupiaków i mięczaków ${ }^{1}$. Zaproponowana definicja stanowi

\footnotetext{
${ }^{1}$ Jest to nawiązanie do klasyfikacji PKD (2007), w której działalność związaną z przetwarzaniem i konserwowaniem ryb oraz skorupiaków i mięczaków umiejscowiono w sekcji C, dziale 10, grupie 10.2. Warto w tym miejscu podkreślić, że omawiana działalność według PKD (2007) stanowi grupę, a jednocześnie klasę klasyfikacyjną, dla której dostępne są wybrane dane. Z tego też powodu należy unikać utrwalania nazewnictwa wynikającego ze starej Klasyfikacji Gospodarki Narodowej (podział na gałęzie i branże). Również pojęcie sektor wydaje się niewłaściwe dla przetwórstwa rybnego, ponieważ to określenie jest przypisane do podstawowych sektorów gospodarki, tj. rolnictwa, przemysłu i usług, zgodnie z teorią trzech sektorów,
} 
Ryc. 1. Wpływ reguł rozwoju na przemiany przemysłu

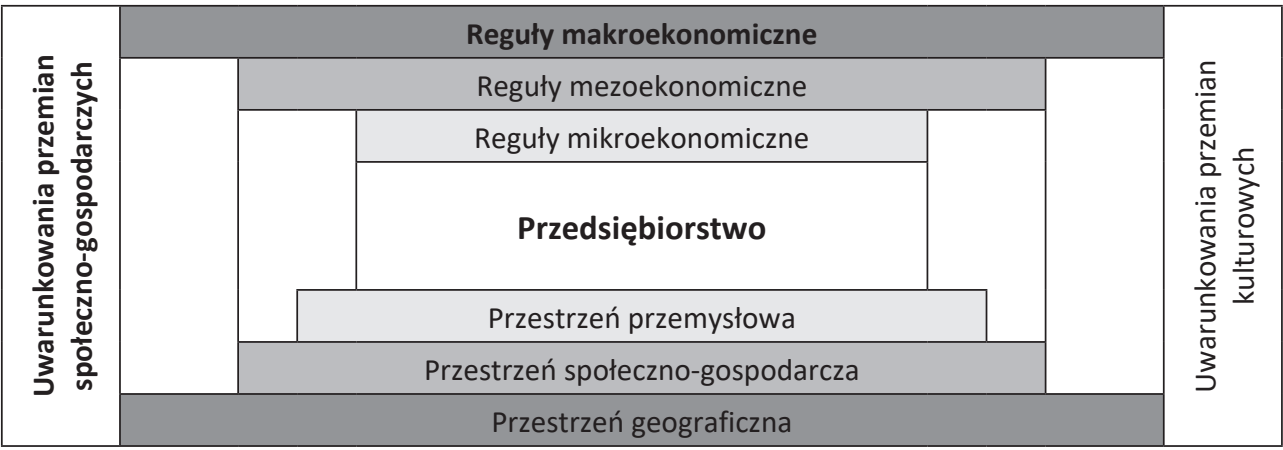

Źródło: Zioło (2006: 13) - zmodyfikowane

Ryc. 2. Miejsce krajowego przemysłu przetwórstwa rybnego na tle problematyki badawczej rynku ryb w Polsce

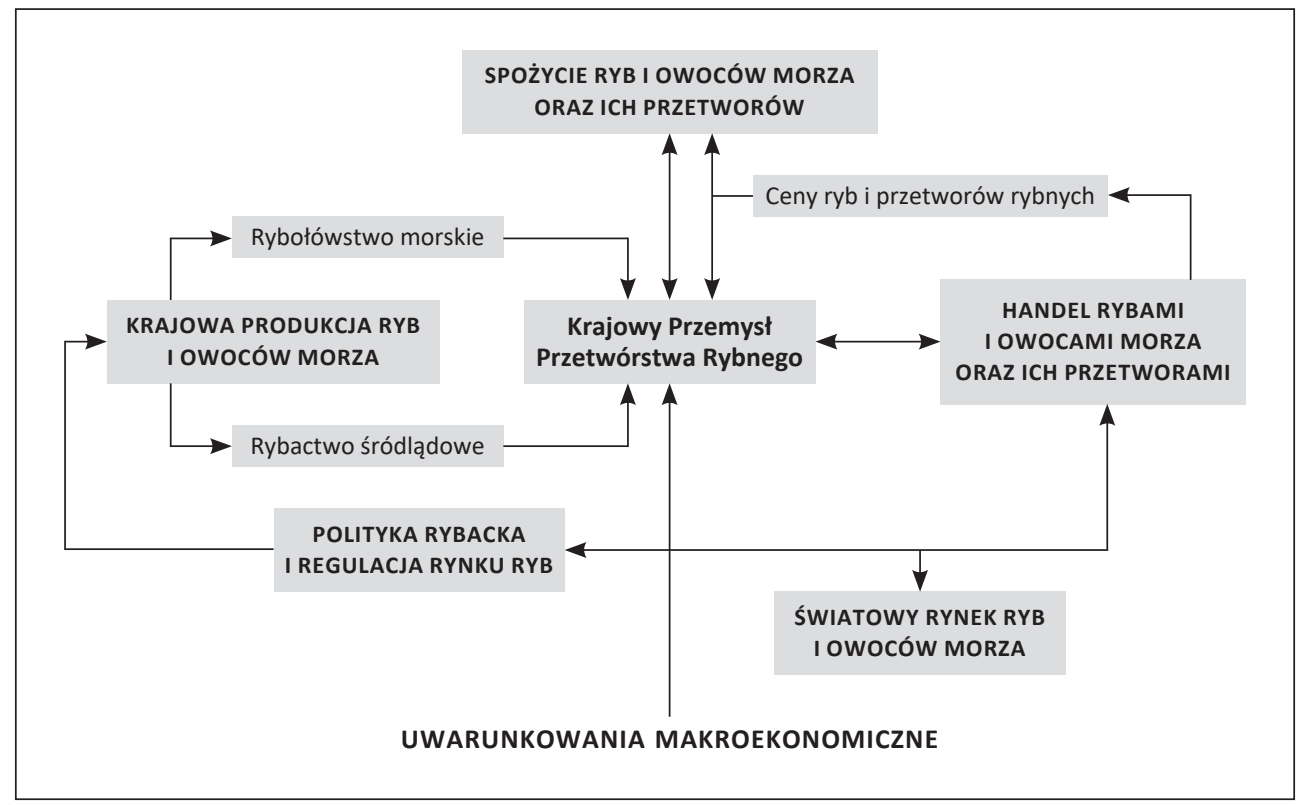

Źródło: opracowanie własne na podstawie kwerendy

punkt wyjścia dla dalszych badań, a jednocześnie pozycjonuje podjętą problematykę w obrębie szeroko rozumianej gospodarki rybnej, która według A. Niegolewskiego (1979: 12) obejmuje połowy, przetwórstwo, handel krajowy i zagraniczny, a także spożycie ryb (ryc. 2). W świetle tej definicji rozwój współczesnego przetwórstwa rybnego opiera się nie tylko na połowach (dalekomorskich i bałtyckich), ale także na akwakulturze, której znaczenie z roku na rok rośnie. Ponadto na skutek polskiej akcesji do struktur europejskich, a pośrednio także na skutek procesów globalnych, zmieniły się

pierwotnie rozwiniętą w latach trzydziestych XX wieku przez A.B.G. Fishera, C. Clarka oraz J. Fourastiego. Brak skalowania czy też niewłaściwe operowanie poziomami klasyfikacyjnymi wprowadzają niepożądany chaos komunikacyjny. 
uwarunkowania rynkowe, $\mathrm{w}$ tym uwarunkowania przestrzenne handlu rybami i produktami rybnymi, m.in. poprzez: szybkość i sprawność obiegu informacji o surowcu i produkcie gotowym, łatwość zawierania kontraktów i umów handlowych, rozwój technologii transportu produktów rybołówstwa oraz ich przetworów. Istotnym zagadnieniem w gospodarce rybnej jest także popyt rynkowy, w tym spożycie ryb, które w Polsce jest ciągle niewielkie w porównaniu do średniego europejskiego spoży$\mathrm{cia}^{2}$. Wszystkie zasygnalizowane problemy są jednak tłem dla przedstawienia przemian strukturalno-przestrzennych w przemyśle przetwórstwa rybnego w Polsce.

\section{PRZEMIANY STRUKTURALNE W PRZEMYŚLE}

Następujące od ponad 25 lat głębokie i radykalne przemiany strukturalne całej polskiej gospodarki, $\mathrm{w}$ tym również przemysłu, na które z jednej strony silnie oddziałują procesy globalizacyjne, a z drugiej rynkowe i pozarynkowe skutki integracji europejskiej, pozwoliły na szybki wzrost konkurencyjności polskiego przetwórstwa rybnego (Czapliński, 2014; Kieliszewska, 2016). Mimo że w skali całego przemysłu przetwórstwo rybne nie odgrywało większej roli i nadal nie stanowi istotnej wielkości statystycznej ${ }^{3}$, to jednakjest uznawane za wzorcowy przykład skutecznie przeprowadzonej restrukturyzacji, a jeszcze bardziej efektywnie wykonanej alokacji środków europejskich, czego potwierdzeniem może być dynamicznie rosnąca wielkość produkcji sprzedanej głównie na rynkach Europy Zachodniej, a w konsekwencji wysoki udział grupy w całkowitych obrotach przetwórstwa rybnego UE, który na koniec 2016 roku wyniósł 6,86\% (ryc. 3, tab. 1).

Tab. 1. Struktura importu i eksportu ryb oraz przetworów rybnych w 2016 roku

\begin{tabular}{|l|c|l|c|}
\hline \multicolumn{2}{|c|}{ Eksport } & \multicolumn{2}{c|}{ Import } \\
\hline kraj & w $\%$ & & w $\%$ \\
\hline Francja & 52,8 & Norwegia & 45,2 \\
\hline Dania & 7,3 & Dania & 7,4 \\
\hline Wielka Brytania & 6,0 & Szwecja & 6,8 \\
\hline Włochy & 5,5 & Niemcy & 5,7 \\
\hline Pozostałe & 5,4 & Chiny & 4,9 \\
\hline Razem & 23,0 & Pozostałe & 30,0 \\
\hline
\end{tabular}

Źródło: na podstawie danych Ministerstwa Finansów, za: IERiGŻ (2017)

Wydaje się, że o sukcesie rynkowym polskiego przetwórstwa rybnego przynajmniej na początku badanego okresu przesądziły sprzyjające uwarunkowania społeczno-gospodarcze, w tym samo wejście Polski do struktur Wspólnoty, które m.in. otworzyło nowe rynki zbytu. Należy podkreślić, że ponad czterokrotny wzrost produkcji

${ }^{2}$ W 2016 roku bilansowe spożycie ryb i owoców morza wyniosło w przeliczeniu na mieszkańca 13,11 kg. Średnia Unii Europejskiej to ok. $23 \mathrm{~kg}$ na osobę rocznie.

${ }^{3}$ Wielkość grupy przemysłowej mierzona np. wielkością zatrudnienia na koniec 2016 roku wyniosła 15,6 tys. pracujących, tj. 4,31\% zatrudnienia w dziale 10 (produkcja artykułów spożywczych). Wielkość produkcji sprzedanej - 9,4 mld zł, tj. 5,13\% produkcji sprzedanej w dziale 10. Udział podmiotów w ogólnej liczbie podmiotów działu 10 - 0,7\%. Obliczenia na podstawie: Wspólna polityka rybołówstwa... (2016); Rocznik statystyczny przemysłu (2016); Rynek Ryb (2010-2017). 
Ryc. 3. Dynamika rozwoju przemysłu przetwórstwa rybnego w Polsce*

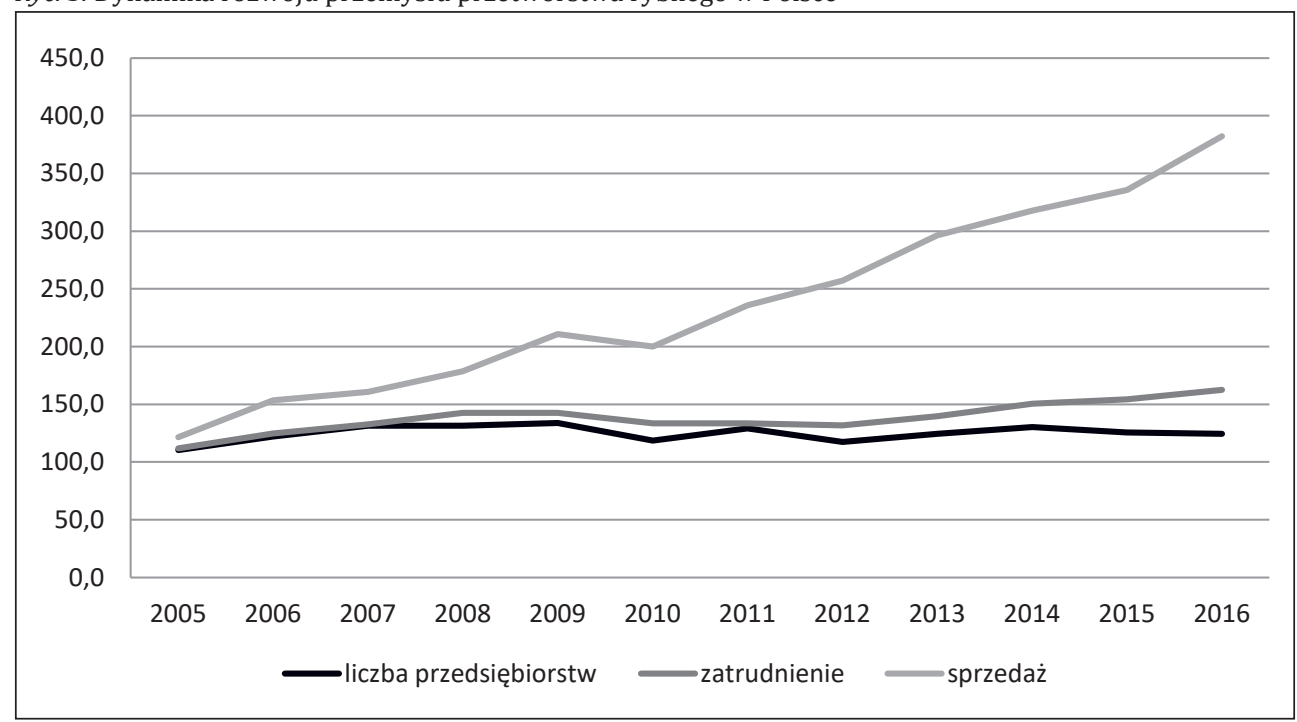

*Wyniki na podstawie przedsiębiorstw przemysłowych zatrudniających ponad dziewięć osób stałej załogi, które złożyły sprawozdania finansowe F-01/I-01, a ich działalność klasyfikowana była według PKD 2007 do grupy 10.2 .

Źródło: opracowanie własne na podstawie analiz rynkowych Rynek Ryb (2010-2017)

sprzedanej polskiego przetwórstwa w ciągu ostatniej dekady był efektem korzyści, jakie płyną z funkcjonowania sektorowych programów operacyjnych adresowanych do całej gospodarki rybnej UE, w tym przetwórstwa ${ }^{4}$. Na sukces badanej grupy w Polsce mogły mieć również wpływ uwarunkowania kulturowe, bowiem działania gospodarcze są zakorzenione kulturowo (Glinka, 2008). W tym kontekście można postawić tezę, że jednym z czynników sukcesu przetwórni mogło być ich położenie w układzie regionalnym i lokalnym, z którym wiąże się miejscowy duch przedsiębiorczości, determinujący postawy pracownicze na wszystkich szczeblach zatrudnienia. Trudno jednak w pełni udowodnić, że część wiodących marek (m.in. Seko, Graal, SperFish) odniosła znaczący sukces nie tylko na rynku krajowym, ponieważ pochodzi z Kaszub, gdzie od ponad 20 lat możemy mówić o fenomenie przedsiębiorczości (Dutkowski, 2002; Czapliński, Szymańska, 2013). Faktem jest, że polskie przetwórnie rybne znacznie lepiej niż ich konkurenci z pozostałych krajów Unii wykorzystały na niespotykaną do tej pory skalę procedury prawno-administracyjne ułatwiające funkcjonowanie na wspólnym rynku oraz środki finansowe gwarantujące dalsze możliwości rozwoju, podkreślając przy tym swój indywidualizm, kreatywność, dużą aktywność w zgłaszanych i prowadzonych projektach oraz zdolność do uczenia się (Nowaczyk, 2013) (ryc. 4).

Pozyskane w ten sposób nakłady umożliwiły rozwój grupy, która przeszła od fazy rozbudowy mocy wytwórczych, poprzez fazę zwiększania efektywności, fazę kreatywności, do sygnalizowanej znacznie wcześniej, zarówno przez analityków rynku, jak

${ }^{4}$ Po akcesji Polski do UE polskie przetwórstwo rybne było i jest beneficjentem realizowanych sektorowych programów operacyjnych: „Rybołówstwo i przetwórstwo ryb 2004-2006”, „Zrównoważony rozwój sektora rybołówstwa i nadbrzeżnych obszarów rybackich 2007-2013”, „Rybactwo i morze” 2014-2020. 
Ryc. 4. Udział eksportu bezpośredniego w przychodach ze sprzedaży produktów

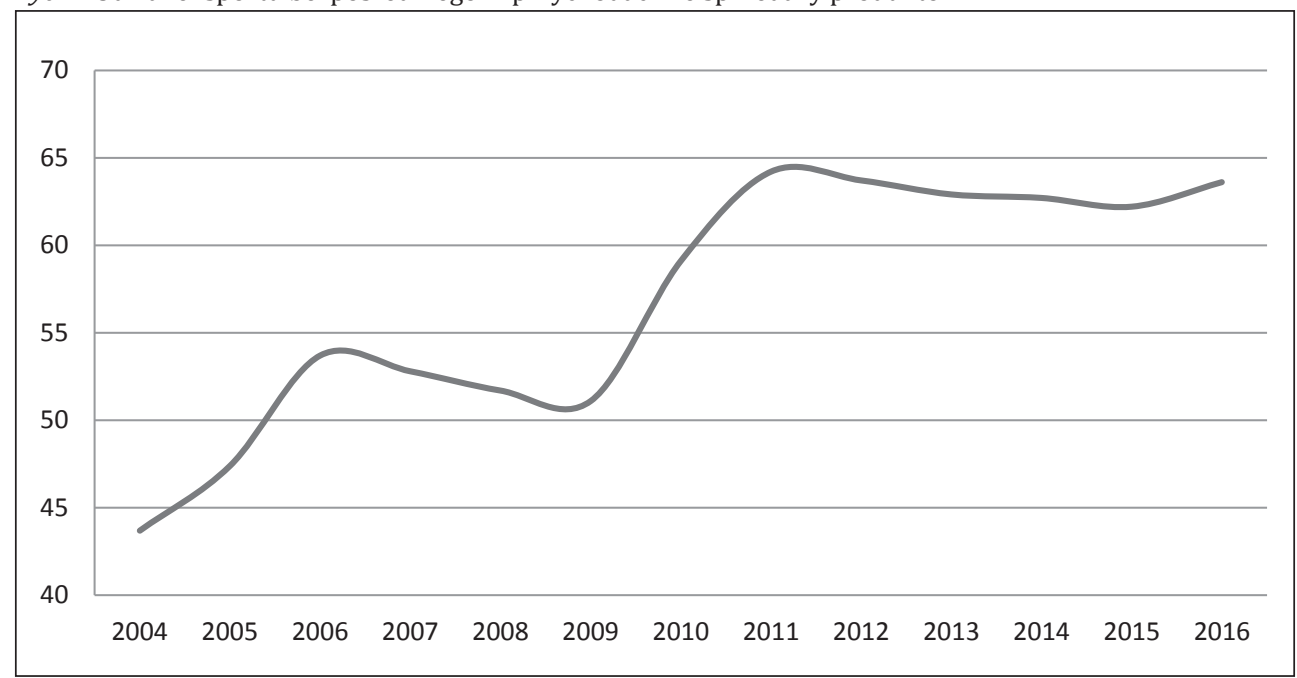

Źródło: opracowanie własne na podstawie danych IERiGŻ (2017)

Ryc. 5. Dynamika inwestycji w przemyśle przetwórstwa rybnego (rok do roku)

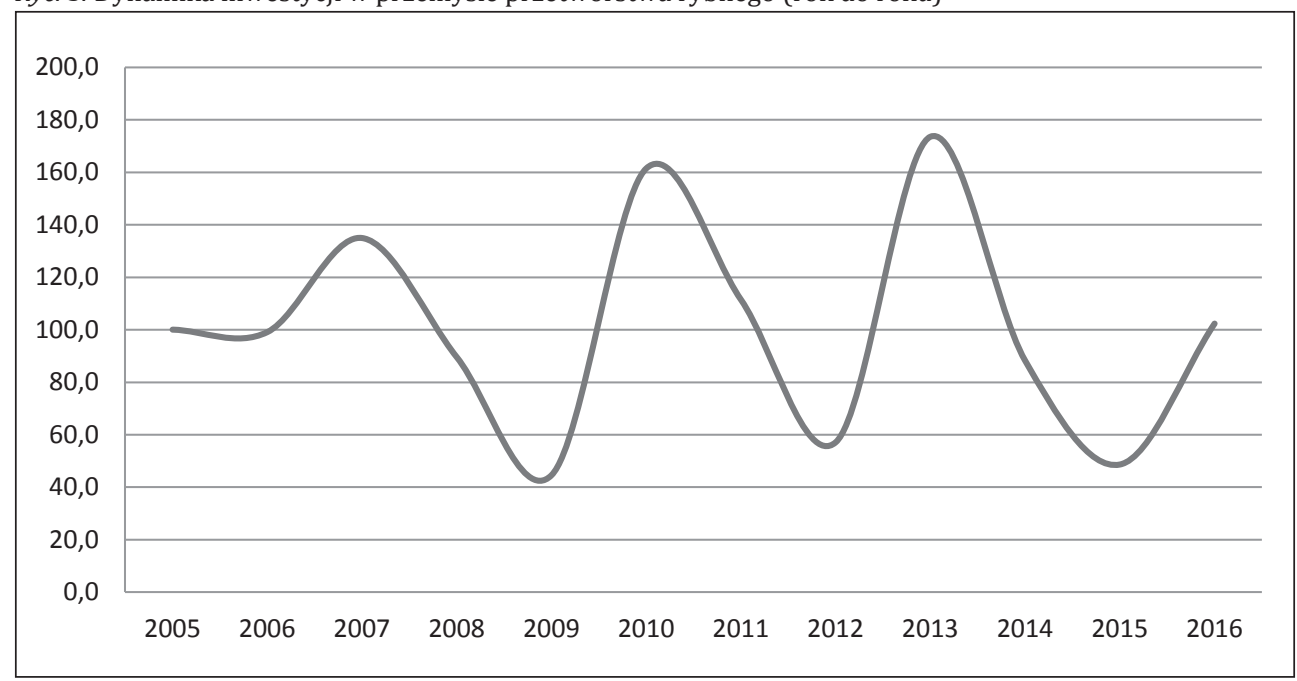

Źródło: opracowanie własne na podstawie analiz rynkowych Rynek Ryb (2010-2017)

i przez samo środowisko przetwórców, koniecznej fazy konsolidacji grupy (ryc. 5). Krajowa konsolidacja zwiększyłaby konkurencyjność, a jednocześnie zmniejszyła ryzyko wrogich przejęć zwłaszcza mniejszych jednostek produkcyjnych przez inwestorów zagranicznych. W opinii wielu ekspertów na skutek krajowej konsolidacji przejmowane przedsiębiorstwa nie zostaną zlikwidowane, lecz dalej będą funkcjonowały jako jednostki produkcyjne, mając swoją specyfikę i specjalizację w ramach większej jednostki organizacyjnej. Potwierdzeniem tego i dobrym przykładem może być spółka Graal SA $\mathrm{z}$ siedzibą w Wejherowie, która od dłuższego czasu realizuje z powodzeniem politykę ekspansywnego rozwoju, polegającą na akwizycjach podmiotów o uzupełniających się 
Ryc. 6. Struktura wiekowa zatrudnienia w przemyśle przetwórstwa rybnego w Polsce

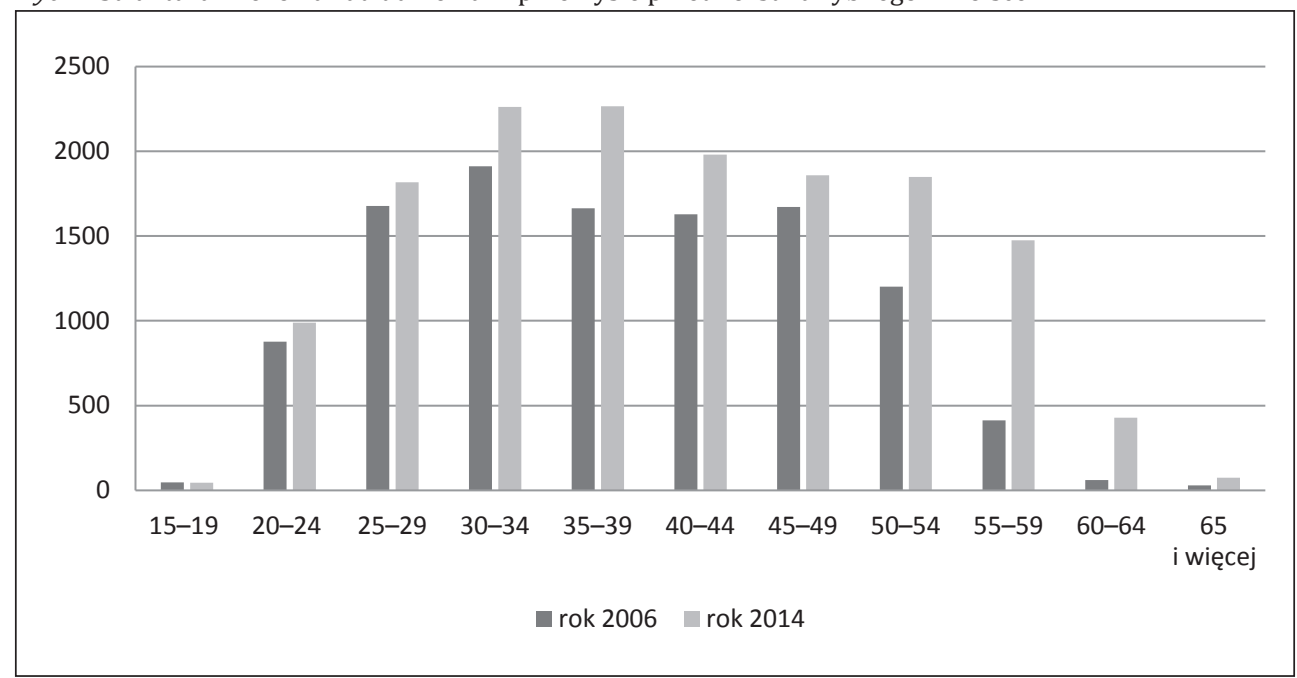

Źródło: grafika na podstawie Kieliszewska (2016: 10)

profilach produkcji lub regionach działania, co niewątpliwie umocni pozycję spółki na rynku przetworów rybnych (Czapliński, 2012; Szczepaniak, 2013).

Gwałtownemu wzrostowi wielkości sprzedaży produktów przetwórstwa rybnego w latach 2004-2016 towarzyszył również wzrost zatrudnienia. Liczba pracujących w tym okresie wzrosła o 62,4\%. Wzrost ten mógłby być znacznie większy, lecz podobnie jak w wielu innych działach polskiego przemysłu postępuje proces kurczenia się produkcyjnych zasobów kadrowych (ryc. 6). W sposób szczególny dotyka to przetwórstwa rybnego, w którym istotna jest nie tylko wiedza merytoryczna, ale również specyficzne umiejętności manualne, tak niezbędne przy obróbce często niestandardowego surowca lub półproduktu. Warto także dodać, że praca fizyczna przy obróbce ryb jest uciążliwa ze względu na warunki termiczne, wilgoć czy bezpieczeństwo i higienę pracy, co wobec faktu, że ponad 65\% zatrudnienia ogółem stanowią kobiety, nie jest bez znaczenia. Dlatego podejmowane są różnego rodzaju działania wobec osób wchodzących na rynek pracy, aby uatrakcyjnić wysokie wymagania stawiane pracownikom produkcji, a jednocześnie poszukuje się pracowników poprodukcyjnych, którzy mimo wieku emerytalnego podjęliby się dalszej pracy lub szkolenia młodszej kadry.

Problem zasobów kadrowych nie dotyczy tylko pracowników produkcyjnych. Istnieją również poważne niedobory pracowników średniego i wyższego szczebla. Jest to efekt niemal całkowitej likwidacji szkolnictwa zawodowego oraz gwałtownie spadającego zainteresowania studiami na kierunkach związanych z przetwórstwem rybnym, m.in. na uniwersytetach w Olsztynie i Szczecinie. Część dużych przedsiębiorstw szkoli personel we własnym zakresie, lecz ze względu na czas i skalę jest to poziom dalece niewystarczający. Sytuacja sprzyja również zatrudnianiu obcokrajowców, głównie Ukraińców, ale do końca 2017 roku ich pozwolenia na pobyt i pracę w Polsce wynosiły zaledwie pół roku, więc wydajność była bardzo ograniczona, zważywszy na fakt, że przeszkolenie trwa ok. trzech miesięcy ${ }^{5}$.

${ }^{5}$ Od 1 stycznia 2018 roku na podstawie rozporządzeń wykonawczych, które były niezbędne w związku ze zmianami wprowadzonymi ustawą z dnia 20 lipca 2017 roku o zmianie ustawy o promocji zatrudnienia 
O ile w badanym okresie wzrosła wielkość produkcji sprzedanej oraz wielkość zatrudnienia, o tyle liczba przedsiębiorstw pozostała na względnie zbliżonym poziomie. Warto jednak w tym miejscu podjąć próbę ich oszacowania, bowiem zarówno w literaturze, jak i samej sprawozdawczości występują znaczące rozbieżności wynikające głównie z różnego rodzaju wyłączeń. Najczęściej podlegają temu przedsiębiorstwa do dziewięciu pracujących (rzadziej do 49 pracujących) lub te, które nie mają określonych uprawnień eksportowych.

Jak wynika z analiz rynkowych przygotowanych przez Instytut Ekonomiki Rolnictwa i Gospodarki Żywnościowej - Państwowy Instytut badawczy w Warszawie, w końcu września 2017 roku w Polsce działały 252 przedsiębiorstwa przetwórstwa rybnego uprawnione do handlu produktami rybnymi na obszarze UE ${ }^{6}$. Spośród nich 11 miało po dwa zakłady. Uprawnienia do eksportu do krajów trzecich posiadało 78 zakładów przetwórczych. Roczna fluktuacja liczby zakładów w okresie 2006-2016 była niewielka i nie przekraczała zwykle 10 jednostek w skali kraju. Warto jednak zauważyć, że wlicza się do tego nie tylko uruchomienie czy zaprzestanie produkcji, ale również jej zawieszenie lub ponowne uruchomienie (Szostak, Drożdż, 2017). Jak wynika z badań bezpośrednich przeprowadzonych przez M. Kieliszewską (2016) na reprezentatywnej grupie zakładów przetwórczych, dominują wśród nich zakłady małe (ok. 41\%) oraz średnie (ok. 32\%), natomiast zakłady duże to niespełna 9\% ogółu przedsiębiorstw.

Odwołując się do prac Z. Zioły $(1997 ;$ 2006), przemiany potencjału przemysłowego (w tym wielkości, natężenia, specjalizacji, funkcji), determinowane w różnej skali regułami ekonomicznymi, w różnym stopniu oddziałują na zmiany struktury przestrzennej przemysłu. Dlatego też współczesna struktura przestrzenna przemysłu przetwórstwa rybnego w Polsce jest wypadkową wielu nakładających się na siebie uwarunkowań i bodźców. Jej obraz ma charakter przekrojowy, stąd konieczność jej stałej interpretacji w szerszej skali czasowej.

Po przystąpieniu Polski do UE, na skutek braku wymaganych europejskich standardów, część przedsiębiorstw przetwórczych została zlikwidowana, a funkcjonowanie pozostałych zredukowane do rynku lokalnego. W latach 2003-2017 liczba zakładów przetwórczych spadła z 305 do 263. Spadek ten objął w zasadzie wszystkie regiony kraju. Relatywnie największą skalę spadków zanotowały regiony nadmorskie (głównie województwo pomorskie). Duża nieregularność aktywności handlowej przedsiębiorstw, która tłumaczy skokowy charakter spadku wartości wskaźnika koncentracji ${ }^{7}$ w okresie przedakcesyjnym, była związana głównie z niezakończonymi procesami transformacji sektora państwowego oraz adaptacją przetwórni sektora prywatnego do wymogów rynku europejskiego (ryc. 7).

i instytucjach rynku pracy oraz niektórych innych ustaw, będzie możliwość ubiegania się o wydanie zezwolenia na pracę sezonową (do dziewięciu miesięcy w roku kalendarzowym) dla obywateli wszystkich państw trzecich.

${ }^{6}$ Poza charakteryzowaną grupą funkcjonują również zakłady dopuszczone do sprzedaży bezpośredniej tylko na rynkach lokalnych w kraju. W końcu września 2017 roku w rejestrze Głównego Inspektoratu Weterynarii znajdowało się 908 takich podmiotów gospodarczych. Wśród nich dominują gospodarstwa rybackie i firmy zajmujące się sprzedażą słodkowodnych ryb żywych i świeżych. Tylko niektóre z nich prowadzą wstępną obróbkę ryb. Szacuje się, że spośród wszystkich znajdujących się w tym rejestrze podmiotów gospodarczych przetwórstwem ryb zajmuje się ok. 70 zakładów.

${ }^{7}$ Wskaźnik koncentracji Florence’a (współczynnik lokalizacji) opisany m.in. w Czapliński, Rachwał, Tobolska, Uliszak (2008). 
Ryc. 7. Zmiany koncentracji przemysłu przetwórstwa rybnego w Polsce w latach 1994-2011 na podstawie wskaźnika koncentracji Florence’a

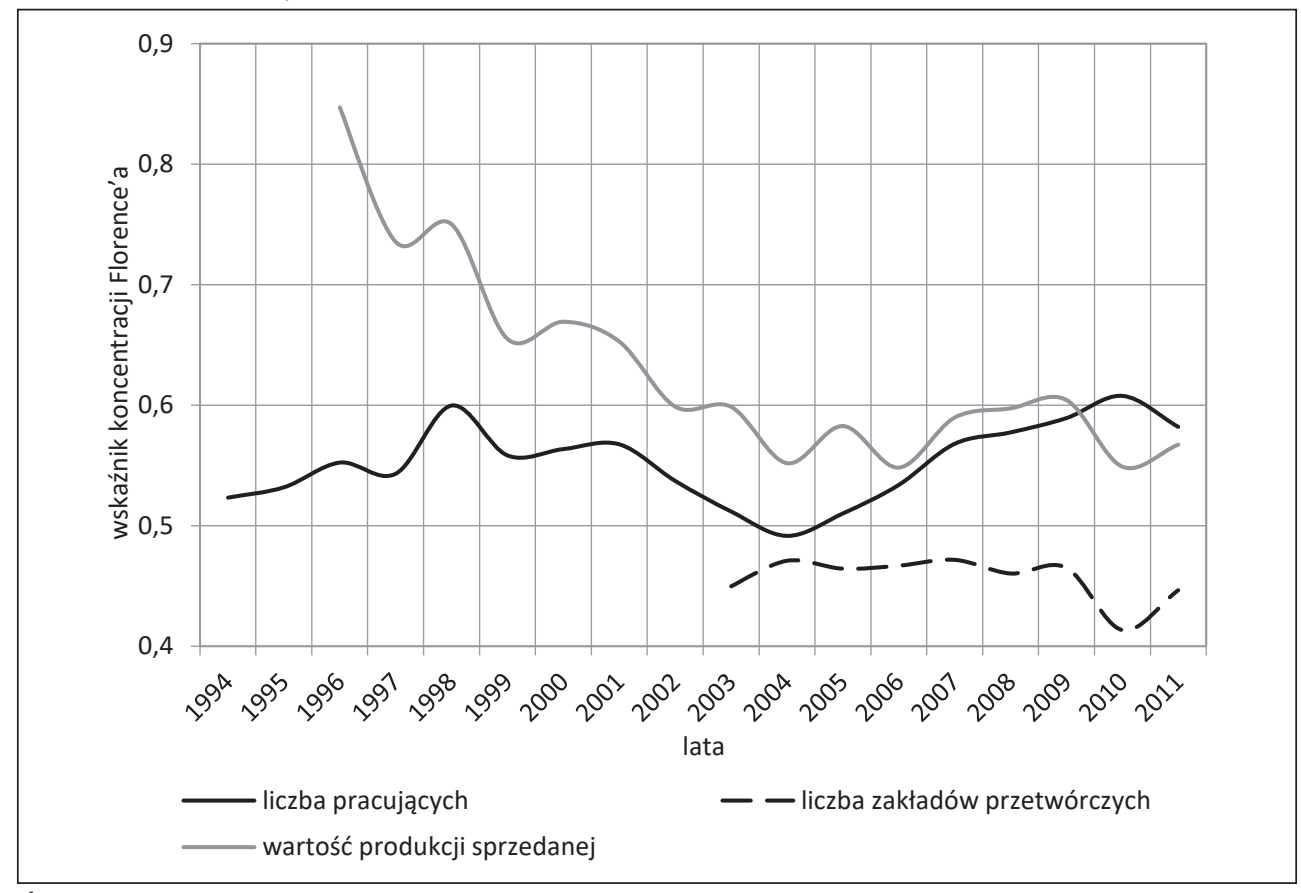

Źródło: opracowanie własne

Ponowny wzrost koncentracji produkcji sprzedanej przetwórstwa w okresie poakcesyjnym (2006-2007), będący skutkiem działania pierwszego sektorowego programu operacyjnego, nie wynikał ze wzrostu produkcji sprzedanej we wszystkich regionach uznawanych wcześniej za wiodące. Znaczny wzrost wartości produkcji sprzedanej uzyskały bowiem przedsiębiorstwa z województw zachodniopomorskiego, wielkopolskiego, podlaskiego i kujawsko-pomorskiego. Natomiast przedsiębiorstwa z województw pomorskiego, a także warmińsko-mazurskiego zaczęły wykazywać spadek wartości produkcji sprzedanej. Za szczególnie interesujący należy uznać okres 2009-2011, w którym początkowo nastąpiły dalsze procesy rozpraszania produkcji przetwórstwa rybnego, a następnie ponowny wzrost koncentracji. Należy to tłumaczyć finalizacją pierwszych inwestycji związanych z działaniem drugiego sektorowego programu operacyjnego oraz przejściem z fazy rozbudowy mocy produkcyjnych do fazy zwiększania efektywności działalności.

Działania inwestycyjne podejmowane w celu podniesienia efektywności funkcjonowania, wykonywane zarówno w regionie nadmorskim, jak i w pozostałych częściach kraju, zwłaszcza w województwach wschodnich i południowych, spowodowały ponowne rozproszenie produkcji sprzedanej (2011-2012). Następny szacowany wzrost koncentracji działalności przetwórczej nastąpił w latach 2013-2014, kiedy to na skutek uruchomienia kolejnej transzy środków z drugiego programu operacyjnego możliwe było wprowadzenie szeregu innowacji, w tym innowacji produktowej, a tym samym wejście w fazę kreatywności. Jako że na innowacje początkowo mogły sobie pozwolić tylko przedsiębiorstwa uznawane za liderów grupy, nastąpił nieznaczny wzrost 
Ryc. 8. Koncentracja przemysłu przetwórstwa rybnego w Polsce na podstawie liczby zakładów przetwórczych

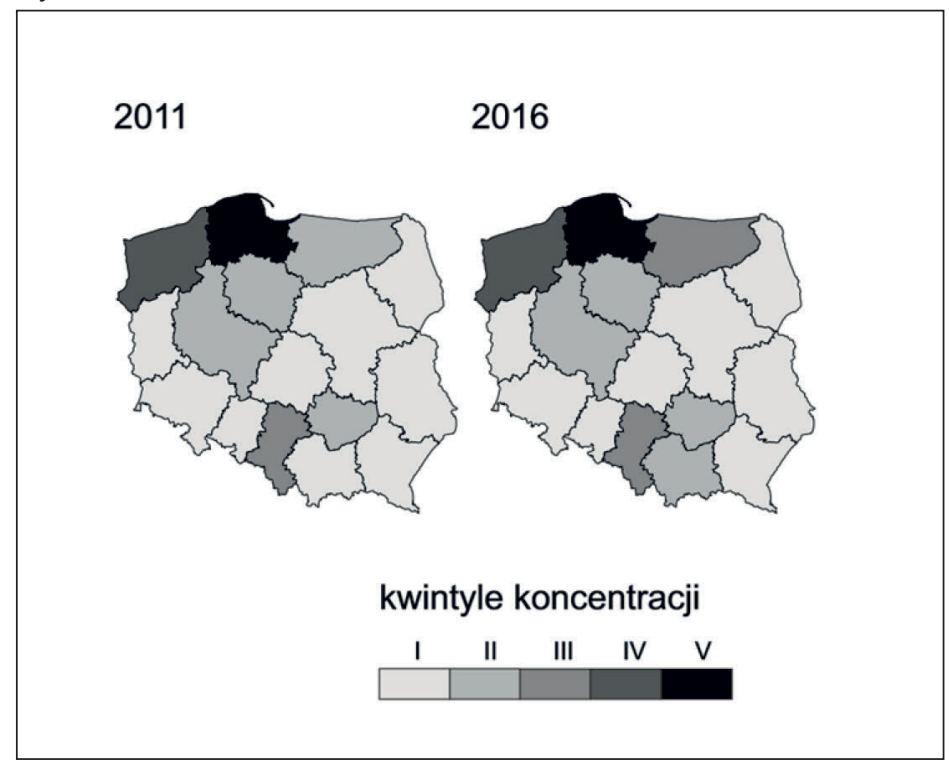

Źródło: opracowanie własne

wskaźnika koncentracji. Stan ten nie trwał jednak długo, bowiem na skutek procesu uczenia się i adaptacji do stale zmieniających się warunków rynkowych grupa relatywnie szybko zbliżyła się w ofercie rynkowej do swoich liderów, a w konsekwencji wskaźnik ponownie spadł.

Wydaje się, że kolejną fazą rozwoju będzie oczekiwana faza konsolidacji, możliwa dzięki wdrażaniu kolejnego programu operacyjnego. Powinna ona wpłynąć na ponowny wzrost koncentracji. Należy jednak podkreślić, że amplituda wahań wskaźnika nie przekracza 0,2, dlatego też opisane cyklicznie występujące procesy koncentracji i dekoncentracji, które wpływają na zmienność i nierównomierność przestrzenną jego rozkładu, nie powodują znaczących i trwałych przesunięć przestrzennych, a jednocześnie sygnalizują kolejną fazę rozwoju tej grupy przemysłowej. Średnie wartości wskaźnika obliczone dla liczby pracujących, a także wartości produkcji sprzedanej (mimo wyraźnych różnic między nimi) pozwalają na ocenę koncentracji przetwórstwa rybnego w kategorii koncentracji średniej lub średniowysokiej. Natomiast wskaźnik koncentracji dla liczby zakładów przetwórczych należy zaklasyfikować do średniej kategorii koncentracji. Co interesujące, zmiany koncentracji produkcji sprzedanej w latach 2004-2016 odbywały się przy stale rosnącym wskaźniku koncentracji zatrudnienia i relatywnie stałym wskaźniku liczby zakładów przetwórczych.

W strukturze przestrzennej przemysłu przetwórstwa rybnego w Polsce nadal największe znaczenie mają zakłady przetwórcze z województwa pomorskiego i zachodniopomorskiego ${ }^{8}$ (ryc. 8). Warto jednak zauważyć, że ich udział w ogólnej liczbie przedsiębiorstw nieznacznie, ale sukcesywnie spada. Na koniec 2016 roku wynosił on

${ }^{8}$ Wymuszona sprawozdawczością agregacja danych na poziomie województw zmusza do dużych uogólnień i nie pozwala na analizę przemian wewnątrzregionalnych. 
53\%, podczas gdy w 2006 roku - 62\%. Natomiast udział obu województw w wartości krajowej produkcji sprzedanej oraz w krajowym zatrudnieniu nie spada, a w ostatnich dwóch latach wykazuje tendencję wzrostową. Może to oznaczać ekspansję przedsiębiorstw nie tylko poprzez zwiększenie produkcji sprzedanej czy zatrudnienia, ale również poprzez procesy konsolidacji, co potwierdzałoby rozpoczęcie kolejnej fazy rozwoju grupy.

\section{ZAKOŃCZENIE}

Sprzyjające uwarunkowania społeczno-gospodarcze, jakie pojawiły się przed polskim przetwórstwem rybnym po akcesji Polski do struktur UE, pozwoliły zdecydowanej większości przetwórni na umiejętne wykorzystanie szans rozwojowych. Wiązało się to z efektywnym wykorzystaniem środków unijnych, które pozwoliły zwłaszcza średnim i dużym przedsiębiorstwom na systematycznie wprowadzane zmiany technologiczne, produktowe, marketingowe i zarządcze, a w konsekwencji na wzrost wielkości sprzedaży. Owa cykliczność ma swoje odbicie również w wahaniach wskaźnika koncentracji produkcji sprzedanej. Małe podmioty, korzystając ze środków pomocowych, mogły przetrwać na rynku. Tym samym struktura przestrzenna przedsiębiorstw nie uległa znaczącym zmianom. Warto w tym miejscu zaznaczyć, że większość dotychczasowych działań w przedsiębiorstwach przetwórczych opierała się na dużych dotacjach zewnętrznych (unijnych). W sytuacji braku tak dużych dotacji istnieje realne zagrożenie konkurencyjności przedsiębiorstw, w tym samodzielnych możliwości sprzedaży produktów. Może to z kolei wymusić proces konsolidacji grupy.

Realnym i stale rosnącym problemem polskiego przetwórstwa rybnego jest również duże uzależnienie od zewnętrznych źródeł surowca oraz zewnętrznych rynków zbytu. Zwłaszcza że zarówno w imporcie, jak i w eksporcie wyraźny jest jeden, dominujący partner. Należałoby więc podjąć próby dywersyfikacji więzi pasywnych i aktywnych przedsiębiorstw np. poprzez poszukiwanie dużych partnerów spoza rynku europejskiego. Takie próby są już podejmowane, ale ich skala jest niewystarczająca. Niewątpliwy wpływ na zmianę silnego uzależnienia polskiego importu i eksportu od jednego partnera handlowego miałaby sygnalizowana wcześniej konsolidacja przedsiębiorstw, zwłaszcza na etapie negocjacji handlowych, a w tym ekonomii skali.

Innym aktualnym problemem polskiego przetwórstwa rybnego jest stale rosnący popyt na wykwalifikowanych pracowników. Jego dynamika na dotychczasowym poziomie może w niedalekiej przyszłości spowodować ograniczenia dalszego rozwoju wielu przedsiębiorstw. Rośnie znaczenie takich czynników, jak koszty pracy i dostępność wykwalifikowanych kadr. Przyczyn wzrostu znaczenia wymienionych czynników należy upatrywać w bardzo tradycyjnym sposobie przetwarzania surowca rybnego. Jego wysoka wrażliwość na obróbkę mechaniczną powoduje, że zakłady przetwórcze korzystają nadal z wieloosobowych taśm produkcyjnych. Ponadto w przetwórstwie rybnym niezwykle cenne są indywidualne, często wynikające z lokalnej tradycji umiejętności obróbki ryb (np. filetowania), które w świetle braku standardu surowca, a jeszcze bardziej upadku polskiego szkolnictwa zawodowego związanego z przetwórstwem rybnym, nabierają specjalnego znaczenia i ceny. Ponadto wysoka pozycja kosztów pracy może oznaczać poszukiwanie nowych miejsc lokalizacji przedsiębiorstw przetwórczych, które nie muszą być związane z atrakcyjną inwestycyjnie, a przez to kosztowną strefą nadmorską. 
Wśród wielu zgłaszanych rekomendacji, zarówno przez przedsiębiorców związanych z przetwórstwem rybnym, analityków rynku, jak i przez badaczy tej grupy przemysłowej, istotnymi wydają się być następujące:

- wprowadzanie na rynek nowych, łatwych i szybkich do przyrządzania produktów,

- koordynacja działań przedsiębiorstw poprzez budowę otoczenia instytucjonalnego,

- utrwalanie polskiej marki w kraju i za granicą,

- podniesienie krajowego spożycia ryb.

Reasumując, należy zgodzić się z diagnozą zaprezentowaną przez C. Christowa (2017: 55), który uznał, że „polski przemysł przetwórstwa rybnego dysponuje obecnie wystarczającym potencjałem i jego dalszy rozwój powinien mieć wyłącznie charakter jakościowy...".

\section{Literatura}

\section{References}

Christow, C. (2017, 30 grudnia). Wyzwania dla przetwórstwa rybnego. 2 Międzynarodowy Kongres Morski. Wnioski i postulaty. Szczecin. Pozyskano z http://klastermorski.com.pl/ wp-content/uploads/2014/07/Kongres-Morski-2014-Wnioski-i-postulaty-opracowanie-iprezentacja-prof.-Cz.-Christowa.pdf

Czapliński, P. (2011). Funkcjonowanie przemysłu przetwórstwa rybnego w Polsce w okresie kryzysu gospodarczego. Prace Komisji Geografii Przemysłu Polskiego Towarzystwa Geograficznego, 17, 114-128.

Czapliński, P. (2012). Consolidation strategy in the polish fishing industry in the light of globalization processes and the European integration. W: P. Slaveykov (red.). Security in the age of global changes. Sofia: University St. Kliment Ohridski, 236-240.

Czapliński, P. (2014). Processes of Transformation of Spatial Structure of Fish Processing Industry in Poland. Prace Komisji Geografii Przemysłu Polskiego Towarzystwa Geograficznego, 25, $151-162$.

Czapliński, P., Rachwał, T., Tobolska, A., Uliszak, R. (2008). Geografia gospodarcza. Przewodnik do ćwiczeń. Poznań: Wydawnictwo Bogucki.

Czapliński, P., Szymańska, W. (2013). The features of economic behavior of the urban population in the ethnic the region of Kashubia (Kashuby / Cassubia). Miscellanea Geographica - Regional Studies on Development, 17(2), 30-37. DOI: https://doi.org/10.2478/v10288012-0032-3

Dutkowski, M. (2002). Fenomen przedsiębiorczości kaszubskiej. W: W. Kosiedowski (red.). Przedsiębiorczość i innowacyjnośćjako czynniki rozwoju regionalnego i lokalnego. Włocławek: LEGA Oficyna Wydawnicza, 495-506.

Glinka, B. (2008). Kulturowe uwarunkowania przedsiębiorczości w Polsce. Warszawa: Polskie Wydawnictwo Ekonomiczne.

Hryszko, K., Kuzebski, E., Lirski, A. (2014). Sytuacja na światowym rynku ryb i jej wpływ na rozwój sektora rybnego w Polsce. Warszawa: Instytut Ekonomiki Rolnictwa i Gospodarki Żywnościowej - Państwowy Instytut Badawczy.

Instytut Ekonomiki Rolnictwa i Gospodarki Żywnościowej - Państwowy Instytut Badawczy (IERiGŻ) (2017). Biuletyn Informacji Publicznej. Pozyskano z https://www.ierigz.waw.pl/ bip

Kapusta, F. (2014). Ryby i ich przetwórstwo w Polsce na początku XXI wieku. Nauki Inżynierskie i Technologie, 1(12), 59-71. DOI: 10.15611/nit.2014.1.04

Kieliszewska, M. (2016). Charakterystyka przetwórstwa rybnego w Polsce w latach 2006-2014 na podstawie kwestionariuszy statystycznych RRW-20. W: I. Psuty (red.). 95-lecie Morskiego Instytutu Rybackiego: aktualne tematy badań naukowych. Tom III - Produkty i przetwórstwo rybne. Gdynia: Wydawnictwo Naukowe MIR, 7-18. 
Kostrzewski, A., Roo-Zielińska, E. (2011). Aktualny stan oraz tendencje rozwoju geografii w Polsce. W: Z. Długosz, T. Rachwał (red.). Priorytety badawcze i aplikacyjne geografii polskiej. Kraków: Wydawnictwo Naukowe Uniwersytetu Pedagogicznego, 9-25.

Niegolewski, A. (1979). Ekonomiczne podstawy rozwoju gospodarki rybnej. Gdańsk: Wydawnictwo Morskie.

Nowaczyk, P. (2013). Próba ukazania wpływu integracji europejskiej na restrukturyzację polskiej floty rybackiej. Problemy Światowego Rolnictwa, 13(28), 172-182.

Rocznik statystyczny przemysłu. (2016). GUS: Warszawa.

Rynek Ryb (2010-2017). Warszawa: Instytut Ekonomiki Rolnictwa i Gospodarki Żywnościowej, 13-27.

Szczepaniak, P. (2013). Konkurencyjność polskiego i niemieckiego przemysłu przetwórstwa rybnego na tle wspólnego rynku Unii Europejskiej. W: J. Górski (red.). Teraz Polska promocja. Warszawa: Fundacja Polskiego Godła Promocyjnego, 37-48.

Szostak, S., Drożdż, J. (2017). Przetwórstwo. W: P. Szajner (red.). Analizy rynkowe. Rynek ryb - stan i perspektywy. Warszawa: Dział Wydawnictw Instytutu Ekonomiki Rolnictwa i Gospodarki Żywnościowej - Państwowego Instytutu Badawczego, 24-27.

Śleszyński, P. (2016). Spór o polską geografię: diagnoza, ocena i propozycje naprawy. W: A. Suliborski (red.). Stan, perspektywy i strategia rozwoju geografii społeczno-ekonomicznej w najbliższych latach (do 2030 roku). Dyskusja międzypokoleniowa. Łódź: Wydawnictwo Uniwersytetu Łódzkiego, 133-156.

Wspólna polityka rybołówstwa UE w liczbach. Podstawowe dane statystyczne (2016). Luksemburg: Urząd Publikacji UE.

Zioło, Z. (1997). Miejsce struktury przestrzennej przemysłu w przestrzeni geograficznej. W: Geografia, człowiek, gospodarka. Profesorowi Bronisławowi Kortusowi w 70 rocznicę urodzin. Kraków: Uniwersytet Jagielloński, 125-132.

Zioło, Z. (2006). Problematyka badawcza efektów restrukturyzacji polskiej przestrzeni przemysłowej. Prace Komisji Geografii Przemysłu Polskiego Towarzystwa Geograficznego, 9, 11-19.

Paweł Czapliński, dr habilitowany nauk o Ziemi w dyscyplinie geografia, w specjalności geografia ekonomiczna. Od 2014 roku na Wydziale Nauk o Ziemi Uniwersytetu Szczecińskiego. Członek rad redakcyjnych czasopism: „Prace Komisji Geografii Przemysłu Polskiego Towarzystwa Geograficznego”, „Przedsiębiorczość-Edukacja” oraz „Rocznik Naukowy Państwowego Uniwersytetu w Chersoniu - Seria Geografia”. Autor ponad 80 publikacji i monografii z zakresu transformacji struktur przestrzennych przemysłu północnej Polski, funkcjonowania i perspektyw rozwoju przemysłu przetwórstwa rybnego w Polsce, przedsiębiorczości młodzieży i osób starszych na obszarach wiejskich oraz wybranych aspektów z zarządzania i administracji samorządowej.

Paweł Czapliński, Ph.D., associate professor of Earth Sciences (economic geography). Since 2014 in the Faculty of Geosciences, University of Szczecin. Member of the editorial board of journals: Studies of the Industrial Geography Commission of the Polish Geographical Society, Entrepreneurship - Education and Scientific Journal of the Kherson State University - Geography. Author of more than eighty publications and monographs on transformation of spatial structures of industry in Northern Poland, performance and prospects of the development of the fish processing industry in Poland, entrepreneurship of young people and the elderly in rural areas and some aspects of the management and administration of local government.

\section{Adres/address:}

Uniwersytet Szczeciński

Wydział Nauk o Ziemi

Pracownia Geoanaliz Społeczno-Gospodarczych

ul. Mickiewicza 18/118, 70-383 Szczecin, Polska

e-mail: pawel.czaplinski@usz.edu.pl 